\title{
Aeromagnetic and electrical resistivity mapping for groundwater development around llesha schist belt, southwestern Nigeria
}

\author{
Cyril Chibueze Okpoli ${ }^{1}$ (i) $\cdot$ Blessing omobolanle Akinbulejo ${ }^{1}$
}

Received: 24 March 2021 / Accepted: 16 September 2021 / Published online: 26 September 2021

(c) The Author(s) 2021

\begin{abstract}
Aeromagnetic and vertical electrical sounding around Ijano, southwestern Nigeria, was investigated for groundwater potential. Aeromagnetic dataset and vertical electrical sounding were acquired and used to investigate the study area. Oasis Montaj, Microsoft Excel and Arc GIS were used to present the results in maps, images and profiles. In order to map out the geological structures of the study area, magnetic image enhancing filters applied to the total magnetic intensity using Geosoft (Oasis Montaj) are reduction to equator, vertical derivative, total horizontal derivative and upward continuation. These filters helped define the lithological boundaries, geological structures, faults, folds and contacts. The lineament of aeromagnetic map was generated from derived field intensity gradients and solutions of Euler deconvolution carried out on the aeromagnetic data using structural index of 0.5 and 1 . The processed image shows the lineaments trends majorly towards NE-SW directions. From these combined results of the study area, consistent aeromagnetic lineament map was generated showing the probable positions and trends of the suspected fractured/faulted zone as well as other basement structures. Hydro-lineament density maps based on lineament were produced from the generalized structure trends in the area. The result from the depth sounding data interpretation indicates three curve types which are $H, \mathrm{HA}$ and $\mathrm{KH}$, where curve type $H$ has the highest occurrence. The results from the vertical electrical sounding data revealed that the areas with the highest hydro-lineament density are good for groundwater prospect and development. The study has led to the delineation of areas where groundwater occurrences are most promising for sustainable supply, suggesting that an area with high concentrations of lineament density has a high tendency for groundwater prospecting. The results from the study show that the aeromagnetic technique is capable of extracting lineament trends in an inaccessible tropical forest.
\end{abstract}

Keywords GIS · Geological structures · Curve types · Hydro-lineament density · Groundwater prospect

\section{Introduction}

In the basement complex, groundwater normally occurs in the porous and permeable substrate which is an underground layer of water-bearing permeable rock of unconsolidated materials such as gravel, sand, confined by impermeable confining bedrock such as shale. It is however more prominent within the weathered and fractured basement where it could either be confined by overlying impermeable and high resistive rocks or remains unconfined but trapped by the low permeable and highly resistive fresh basement. Aquiferous zones are usually found to have a wide range of undulating

Cyril Chibueze Okpoli

cyril.okpoli@aaua.edu.ng

1 Department of Earth Sciences, Adekunle Ajasin University, Akungba-Akoko, Nigeria spatial geometry which affects the groundwater potentiality of a given formation (Steinich et al. 1999). Thus, in most cases basement relief determines the thickness of the aquifer.

Magnetic method of geophysical prospecting is very vital in investigating subsurface geology and identifying anomaly resulting from the magnetic properties of the underlying rocks. It is found to be very successful in delineating various subsurface formations due to relatively high susceptibility contrast between basement rock and sedimentary unit (Emujakporue et al. 2017). In this regards several works have been carried out for the purpose of delineating basement structural pattern using aeromagnetic data (Osinowo et al. 2013; Steinich et al. 1999; Srivastava 2002; Emujakporue et al. 2017; etc.). Information about subsurface geometry, depth, thickness and lateral extent of the impermeable crystalline basement is very crucial for accurate hydrogeological characterization of a given formation. Magnetic method 
integrated with electrical resistivity can harmoniously be used to locate the permeable layer, fractures and estimate their thicknesses thereby providing possible relationship between aquifers and related features (Batista-Rodriguez et al 2017).

Several techniques of mapping basement as a source of magnetic anomaly are being practised by many authors. These are grouped into graphic and computer modelling techniques (Osazuwa 1988; Gunn 1997). Graphic techniques are based on the fact that deeper magnetic sources are associated with broader anomaly while shallower sources are associated with narrower anomaly. Thus, the techniques can be accomplished by approximating the magnetic source with simple geometry. Depth estimation is achieved using model curve atlas produced by many authors (Parker 1963; Essa and El-Hussain 2017; Rambabu and Sinha 1986). Manual matching of the anomaly type curve is however timeconsuming and restricted to the curve type whose model is available (Gunn 1997). With the advent of computer and its routine capabilities of modelling by trial and error, several computer modelling algorithms were developed based on the computation of the effect of various geometries or sum of sources of geometries on the shape of the anomaly (Won and Bevis 1987). The modelling has significant advantage and it reduces the tediousness and cumbersomeness of graphic techniques. The most popular modelling and inversion techniques are Euler deconvolution developed by Reid et al. 1990; analytic signal (Nabighian 1984; Roest et al. 1992), spectral analysis (Spector and Grant 1970) all of which produce geological model with anomaly effect which matches the observed magnetic anomaly. The Euler deconvolution however requires the choice of structural index which is challenging where the survey area contains a range of sources with significantly different geometries (Gunn 1997). The computation of analytical signal on the other hand leads to the amplification of the noise on a real data (Qin 1994). Spectral analysis however has the advantage of estimating the depth of anomaly source approximated by a prismatic block based on the logarithmic radial energy spectrum of the total magnetic intensity. The spectrum consists of a straight line whose gradient is related to the average depth to the tops of the prisms.

In this work, high-resolution aeromagnetic and electrical resistivity data were used to, respectively, estimate the topography of fractured and crystalline basement of part of Ilesha called Ibodi. The work is based on the assumption of the fact that groundwater in crystalline basement mainly occurs in fractured and weathered zone of the basement (Musa et al. 2013). Hence, the crystalline fresh basement beneath fractured basement serves as underground water repository trapped by fresh impermeable crystalline and denser materials such as granite, basalt or shale.
The difficulty facing the geologist and geophysicist specializing in groundwater exploration has been the area of coverage as a result of limitations in terms of accessibility most especially urban areas. In this situation, detail geophysical investigation is often problem and accurate interpretation of results is not guaranteed. In solving this problem, the aeromagnetic survey has proved to be successful in this regard by mapping geological structures relating to groundwater occurrence on a regional scale. This is because aeromagnetic survey has the advantage of covering region of about 500-5000 square kilometres and it can be integrated with other geophysical techniques for groundwater exploration.

Chifu et al. (2019) applied Aeromagnetic and Electrical Resistivity Data for Mapping Spatial Distribution of Groundwater Potentials of Dutse, Jigawa State, Nigeria. The results obtained were harmoniously used to map the spatial distribution of groundwater resources of the study area based on aquifer thickness and the basement geometry. It is however observed that such formation could equally be vulnerable to anthropogenic pollution due to persistent agricultural activities within the area. It is therefore recommended that for domestic exploitation of the resources within the area, assessment of groundwater quality should be carryout.

Djamel Boubaya (2017) combined Resistivity and Aeromagnetic Geophysical Surveys for Groundwater Exploration in the Maghnia Plain of Algeria Djamel. This study demonstrates the important contribution of the resistivity and the aeromagnetic techniques as effective geophysical tools for exploring deep aquifers, a principal source of groundwater in the Maghnia plain of western Algeria.

Joel et al. (2016) carried out regional groundwater studies using aeromagnetic technique. They observed that aeromagnetic techniques proved to be useful in studying groundwater occurrence and structures where there is an absence of hydrogeophysical equipment.

None of these earlier studies integrated aeromagnetic and electrical resistivity mapping techniques to determine the spatial distribution of groundwater in the study. This study presents data and interpretations from aeromagnetic dataset and vertical electrical sounding which was process with Geographic Information System (GIS), with a specific objective of providing an integrated approach to the understanding of the spatial distribution of groundwater and its development around Ifewara-Ilesha schist belt.

\section{Description of the study area}

\section{Location and accessibility of the study area}

The study area covers a land expanse of 16 square kilometres, with host of villages and an ancient Town of Ibodi in the southwestern part of Nigeria (Fig. 1). Ibodi Town is 


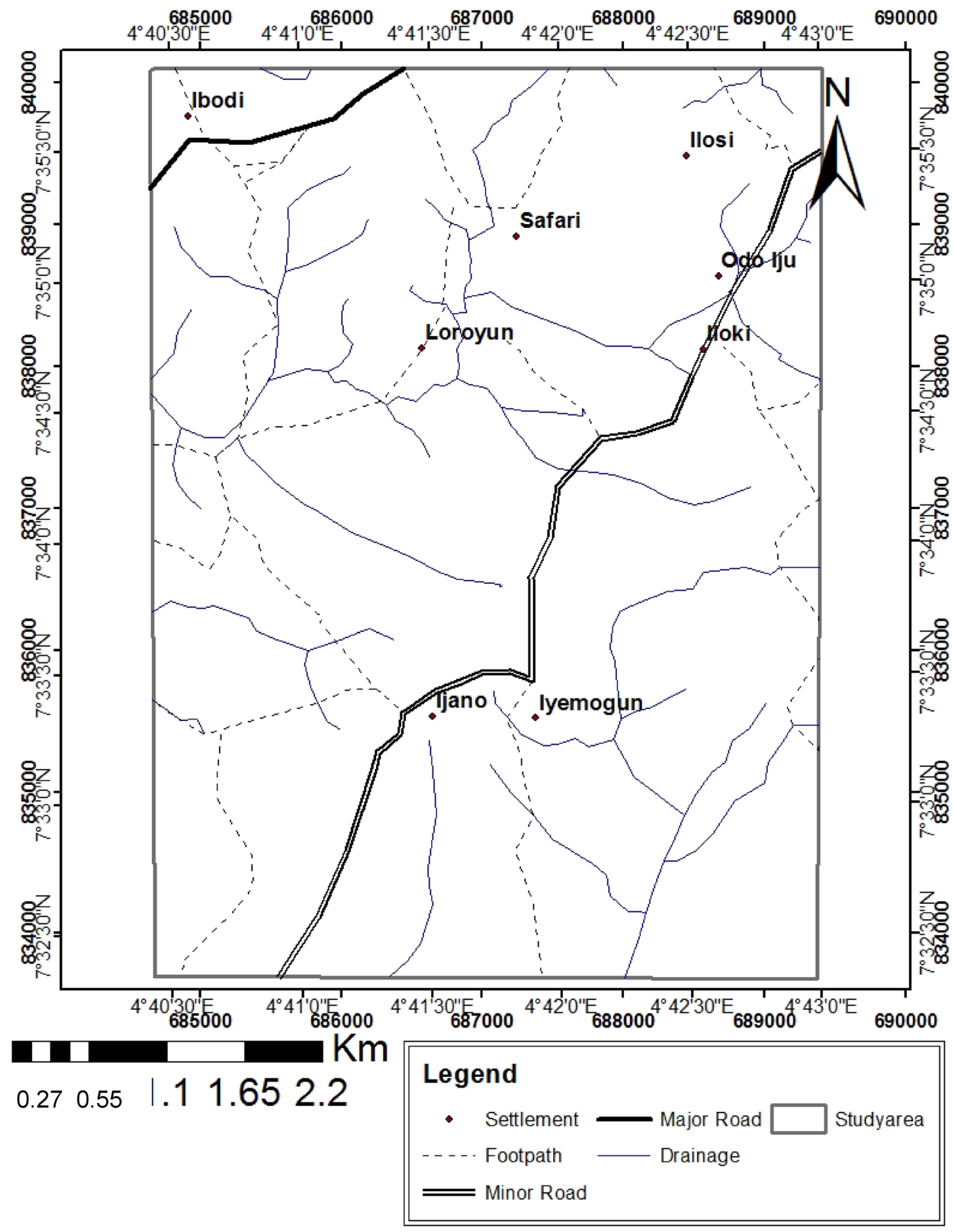

Fig. 1 Location Map of the Study Area

located in the Atakumosa East local area of Osun State, Southwest Nigeria. The study area lies within latitude $7^{\circ}$ $30^{\prime} 20.82^{\prime \prime} N$ to $7^{\circ} 33^{\prime} 2.89^{\prime \prime} N$ and longitude $4^{\circ} 48^{\prime} 44.83^{\prime \prime}$ $E$ to $4051^{\prime} 28.58^{\prime \prime} E$. The study area is about $15 \mathrm{~km}$ south of Ilesha Town. It is accessible through the Ibadan-Ilesa highway in the northern part and a series of old bypass of network of roads to Ile-Ife and Ipetu-Ijesa in the southern part. Other means of accessibility is through network of un-tarred roads and footpaths joining villages and 


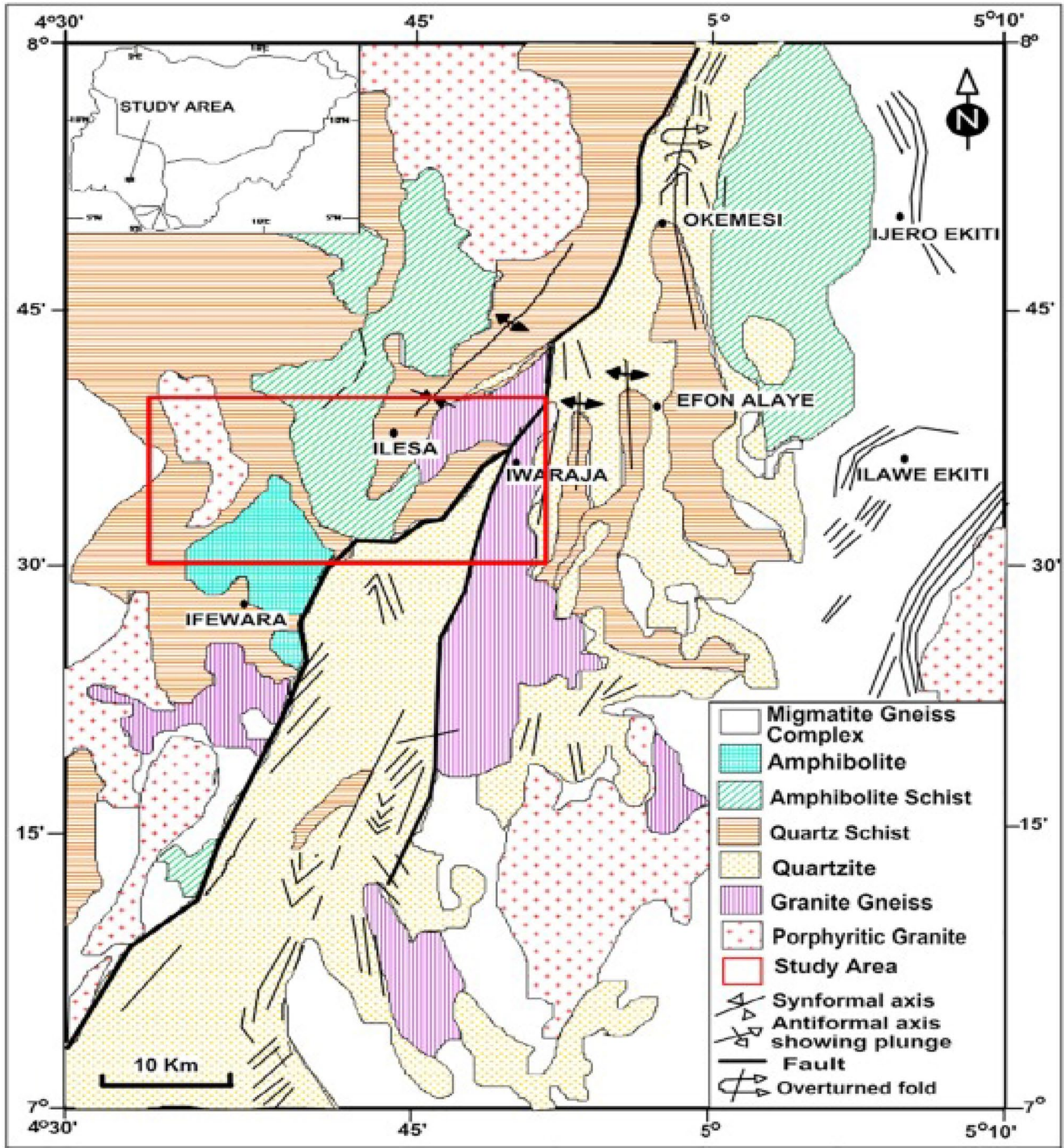

Fig. 2 Geology Map of Ilesha Area (Modified after Akinlalu et al. 2018)

farmlands. Vegetation is partially thick and much has been cleared for farmland.

\section{Geomorphology, climate and drainage pattern}

The study area is generally an upland and highly resistant to both weathering and erosion. The topography of the area is generally undulating and punctuated in some areas by hilly ridges and gently steeping land forms, which consist of lateritic soils, clay, sandy clay, top soil and low lying outcrops in the few exposures in the study area. The study area is generally over $400 \mathrm{~m}$ above sea level except few areas that fall just below $400 \mathrm{~m}$ with some hills at the northern part of the study area. The ridges are formed by quartz-schist 


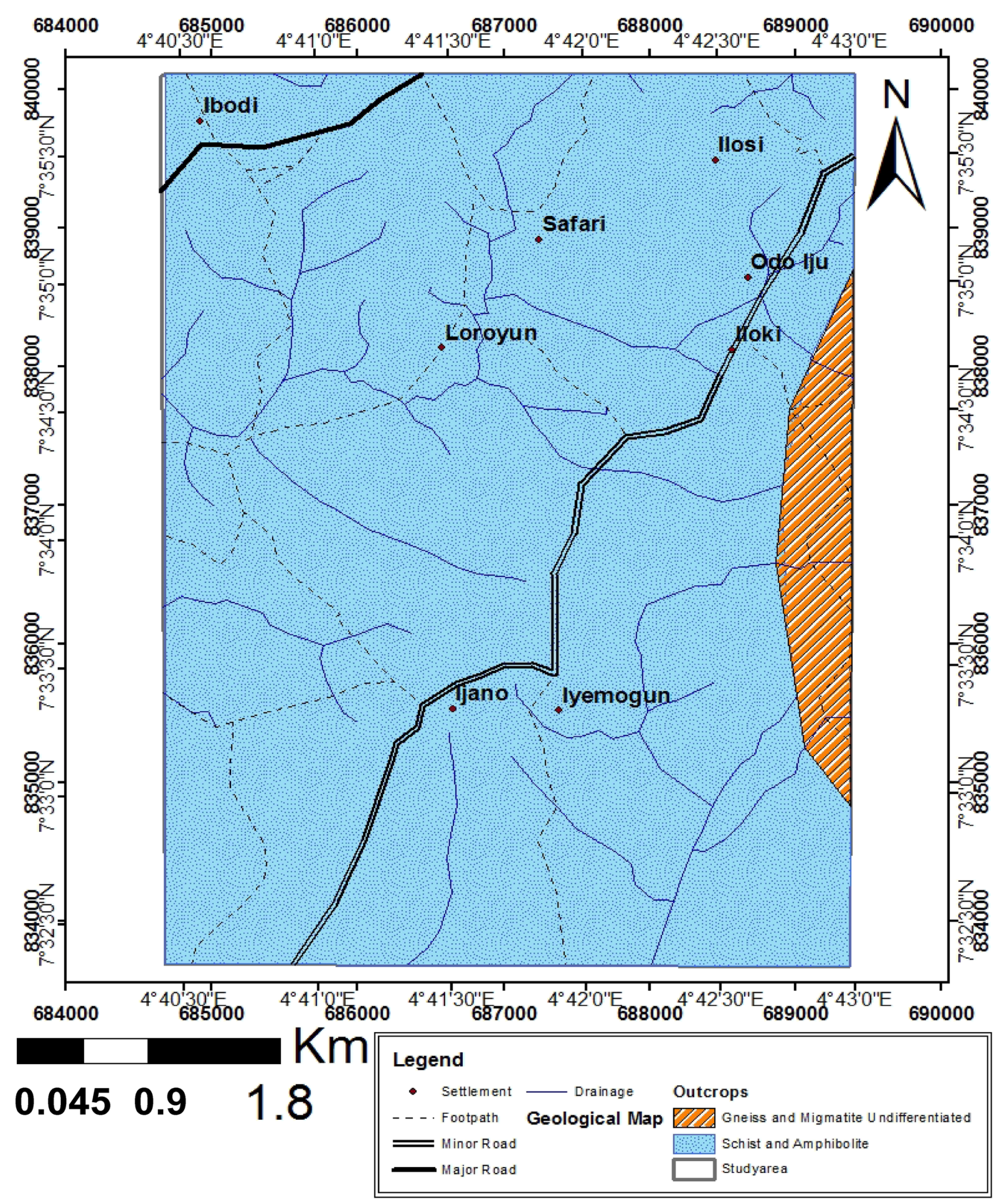

Fig. 3 Geological Map of the Study Area 


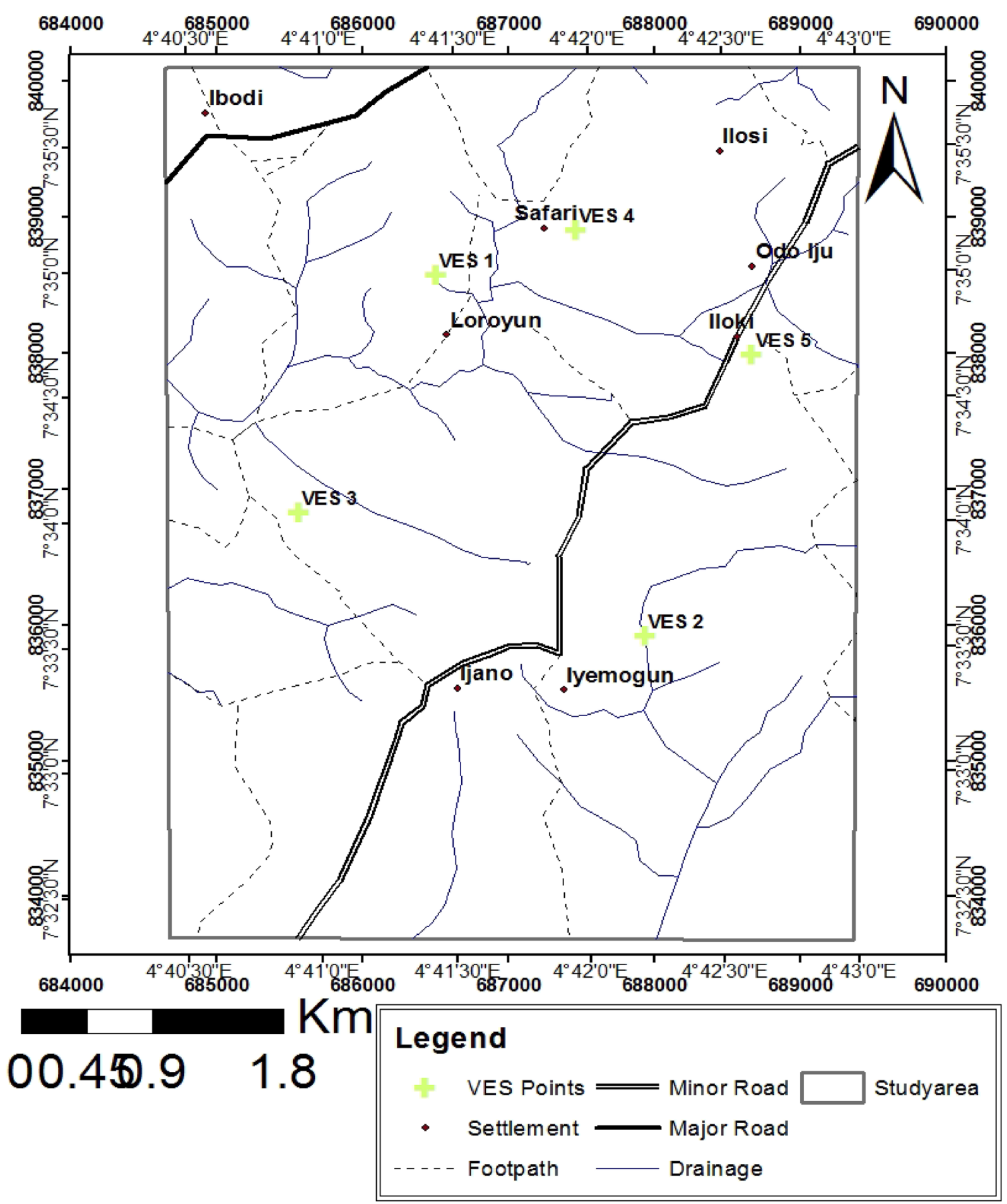

Fig. 4 Data Acquisition Map of the Study Area

or quartzite that rises abruptly from enveloping basins and trend in west to east section. The drainage system is dominated by dendritic pattern of streams flows, which is typical of the basement complex terrain and are structurally controlled.
Regional Geology of the Study Area.

The geology of Ilesha area has been described in detail by several authors (Kayode et al. 2011; Ajayi and Ogedegbe 2003). It consists of Precambrian rocks which form the Basement Complex. The major rocks associated with 
Fig. 5 Total Magnetic Intensity Map of the Study Area

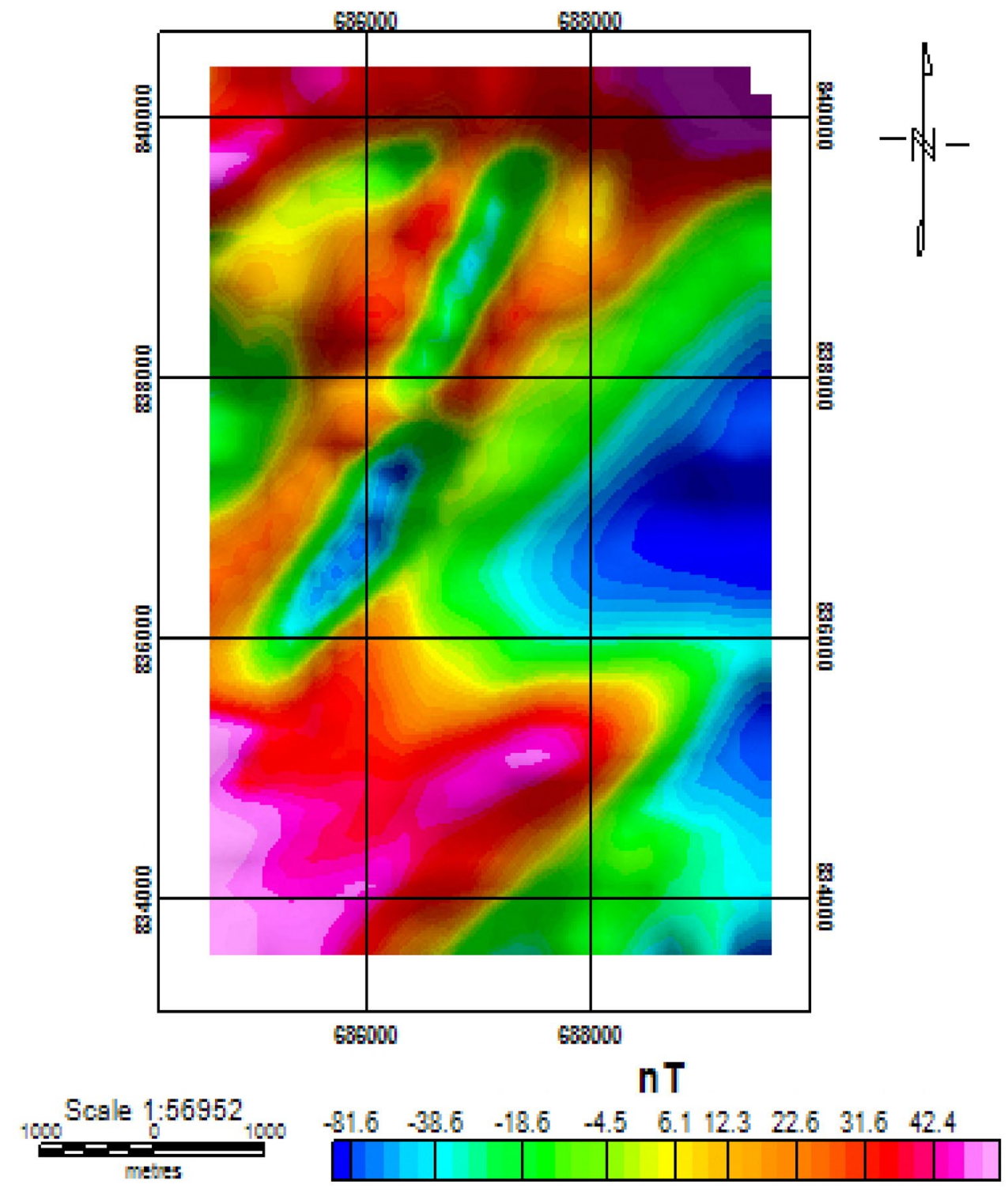

the area form part of the Proterozoic schist belts in Nigeria as shown in Fig. 2. Quartz-schist, quartzite, amphibolites, granite-gneiss amphibolites schist and migmatite-gneiss complex are the major rocks in Ilesha as delineated. Other minor rocks according to these authors are garnet, quartz chlorite bodies and dolorites.

The amphibolite and the hornblende gneiss are the mafic and intermediate rocks in southwestern Nigeria (Oyinloye 2011). The amphibolites are made up of the massive melanocratic and foliated amphibolites. In Ilesha and Ife areas these amphibolites occur as low lying outcrops and most are seen in riverbeds. The massive melanocratic amphibolite is darkish green and fine grained. Commonly hornblende gneiss outcrops share common boundaries with the melanocratic amphibolite. This rock (hornblende gneiss) crops out at Igangan, Aiyetoro and Ifewara, along Ile-Ife road as low lying hills in southwestern Nigeria. The hornblende gneiss is highly foliated, folded and faulted in places. Amphibolite occurs widely in southwestern, Nigeria in Ile-Ife area and at Ibodi and Itagunmodi in Ilesha area. Most outcrops of the massive melanocratic amphibolites are exposed in streams and river channels in these areas. The overburden soil is strikingly red due to the presence of hematite and magnetite liberated during the weathering of the amphibolites to form the overburden soil.

\section{Local Geology of the Study Area}

The study area is underlain by migmatite, porphyritic granite, amphibolites, amphibolite schist, quartz schists and 
Fig. 6 Reduction to Magnetic Equator of the Study Area

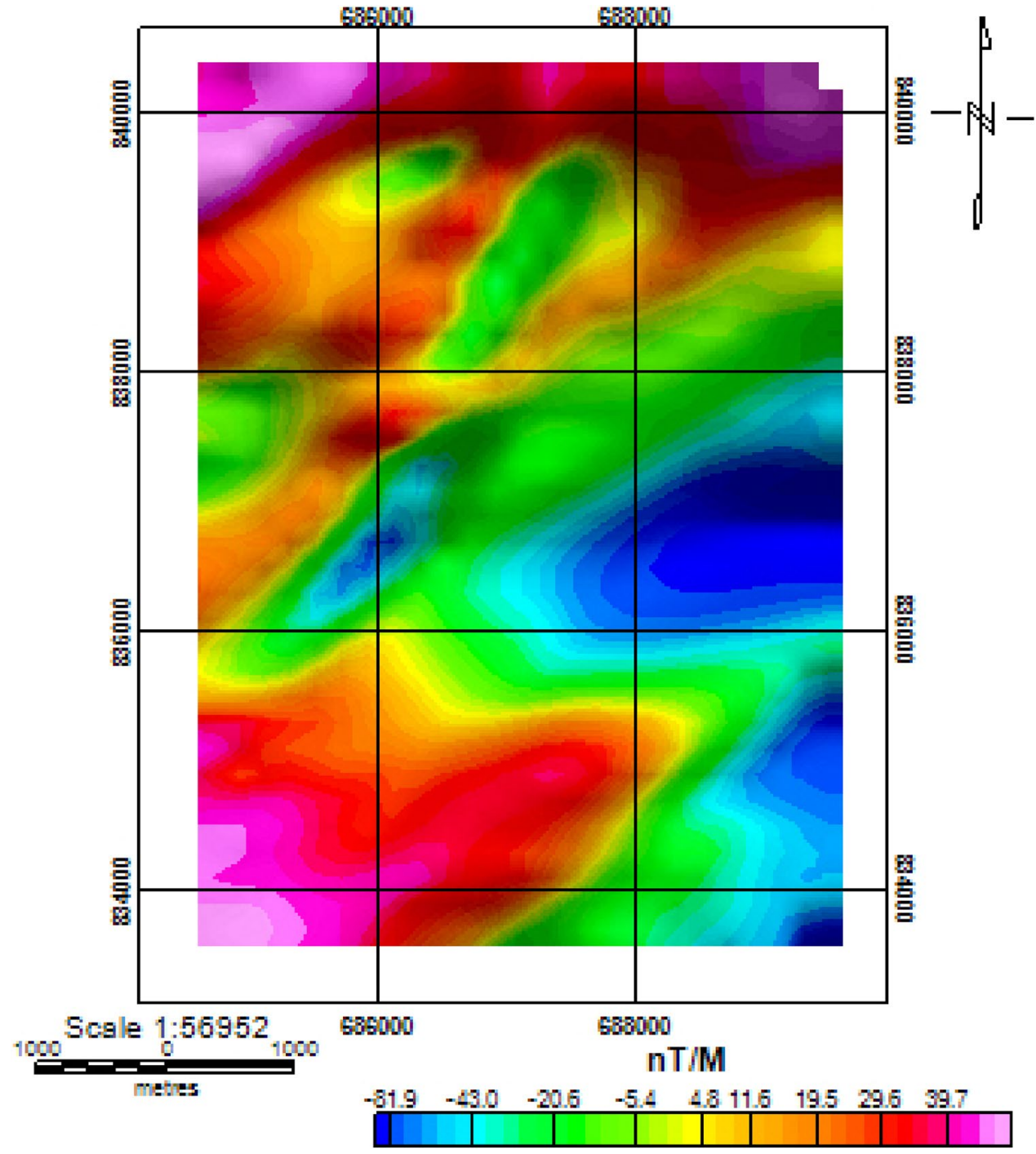

quartzite intruded by granite now deformed into gneisses (Fig. 3).

The rocks have experienced shearing and fracturing. They are banded, foliated and display structures suggestive of poly deformation (Ajibade 1979; Elueze 1982; Anifowose and Borode 2007; Ademeso et al. 2013). Migmatite-gneiss-quartzite complex which comprises biotite and biotite hornblende gneisses, quartz schists and small lenses of calc-silicate rocks. The gneisses and migmatite are ubiquitous and are intimately mixed together that they are hardly separable on the field. The gneiss may be divided into two types; vis-à-vis the biotite gneiss and the banded gneiss. The rock sequence consists of basically weathered quartzite older granite. The basement complex rocks of Nigeria are made up of heterogeneous assemblages (Rahaman 1988).

\section{Materials and methods}

\section{Aeromagnetic data}

\section{Field procedure}

An aeromagnetic map on a scale of 1:50,000 was acquired from the Nigerian Geology Survey Agency (NGSA). The aeromagnetic data were acquired at a nominal flying altitude of $152 \mathrm{~m}$ (about 500ft) with flight lines spaced $2 \mathrm{~km}$ in the direction 60/240 (dip/azimuth) degree and contour interval of 20nT. Magnetic instruments used are air plane, Magnetometers, Magnetometer Stinger, digital data acquisition system track recovering system, recording altimeters, magnetic compensation unit and Doppler navigation system. Regional correction was based on IGRF (1 January 1974). 
Fig. 7 Upward Continuation Map of the Study Area

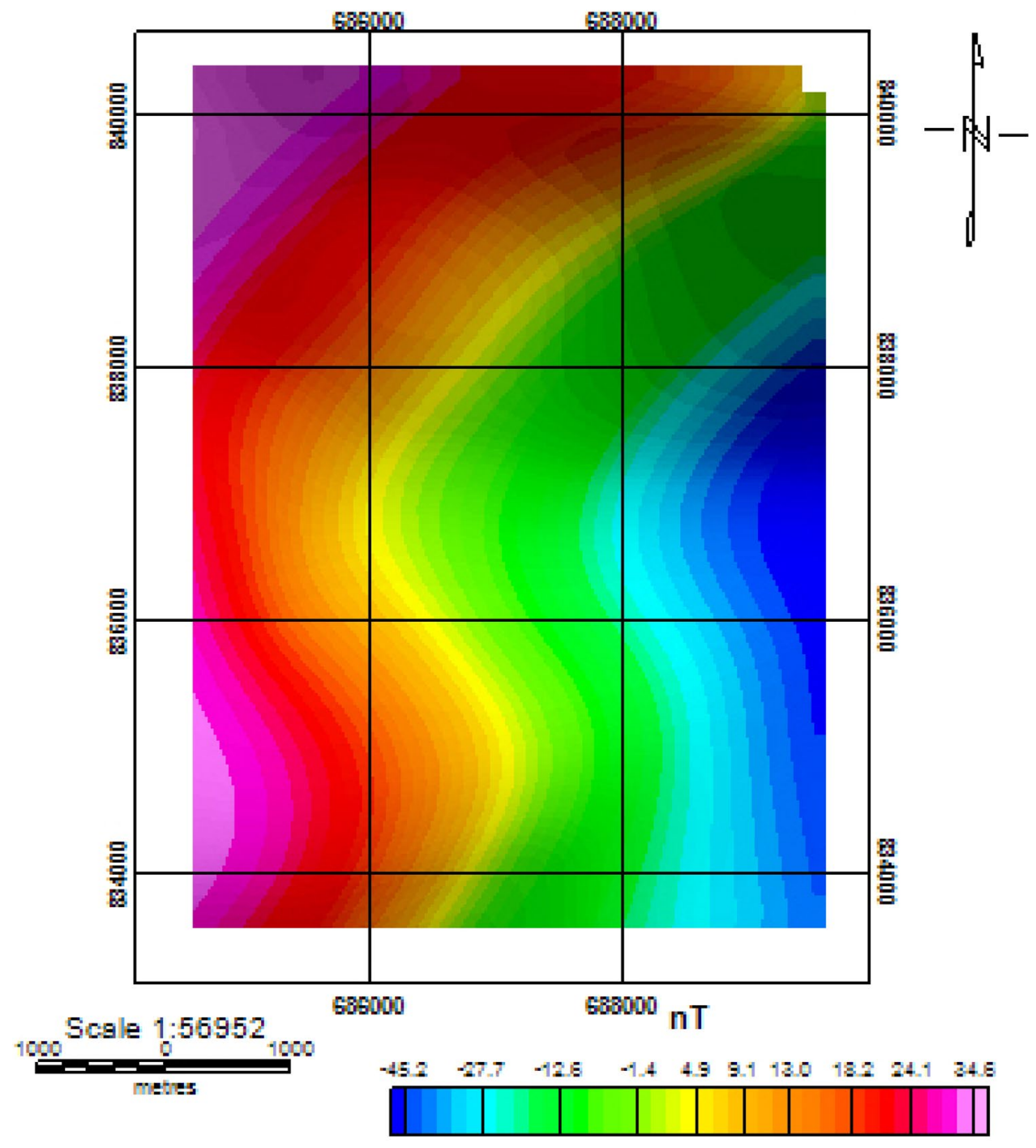

\section{Euler deconvolution}

The Euler deconvolution of the aeromagnetic field data was carried out to determine the locations and depths of the source bodies, and other geological sources in the area, using a structural index of 0.5 and 1 . The structural trends obtained from the Standard Euler Solutions from the Euler deconvolution of the aeromagnetic data were imported into ArcGIS 10.5 software environment, geo-referencing and digitized to generate lineament map which were used to characterize the linear features in the study area and rose diagram was generated using Georient software. Estimation of depth to magnetic sources recognized as contacts between rocks, fracture, fault and sheared zones were evaluated with the aid of spectral analysis frequency (Spector 1971; Thompson 1973; Nabighian 1974; Thompson 1982). Following the interpretation of the aeromagnetic data was used in attempt $x$ - and $y$-derivatives of the magnetic intensity data. 
Fig. 8 Residual Magnetic Anomaly Map of the Study Area

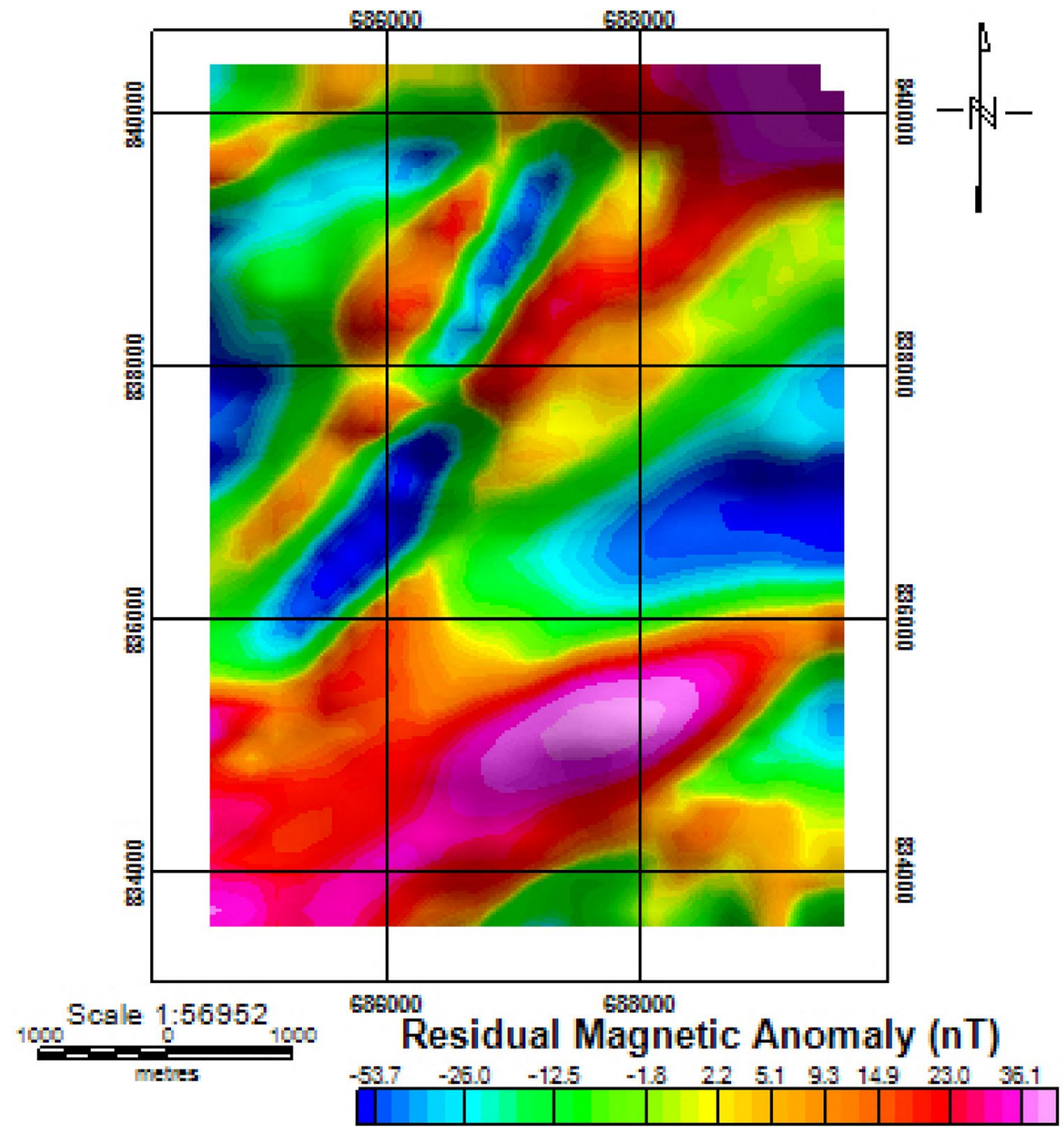

to further define the structures delineated from the aeromagnetic interpretation.

\section{Vertical electrical sounding}

The materials and instrument used for vertical electrical sounding include the following: location, topographic and geological maps of the study area, Global Positioning System (GPS), calibrated polyethylene twain, steel electrodes, reels of cables, hammers and resistivity metre.

\section{Field procedure}

The Omega resistivity meter equipment was used for the VES survey. The vertical electrical resistivity sounding utilized Schlumberger configurations. In Schlumberger array, the separation between the current electrodes (AB) is successively expanded while the two potential electrodes (MN) have a short separation and remain partially stationary at the depth sounding position while The geo-electric survey is such that the minimum electrode spacing " $\mathrm{AB} / 2$ " and gradually increase to a maximum spread length "AB/2" of $100 \mathrm{~m}$. A total of 5 VES points were occupied to cover the study area (Fig. 4).

\section{VES Data Presentation and Interpretation}

The sounding data were presented as sounding curves, which are plots of apparent resistivity values against electrode separation $(\mathrm{AB} / 2)$ on bi-log graph. The Schlumberger array is used to investigate the change of resistivity with depth (Griffiths and Turnbull 1985; Griffiths et al. 1990). The measured unit is the apparent resistivity, $\rho a$, which is the product of a geometrical factor, $K$, and the quotient of the measured potential, $\Delta V$, and the source current, $I$. The apparent resistivity is plotted versus $A B / 2$ in metres on bilogarithmic paper resulting in a VES curve. The VES 
Fig. 9 X-Derivative Map of the Study Area

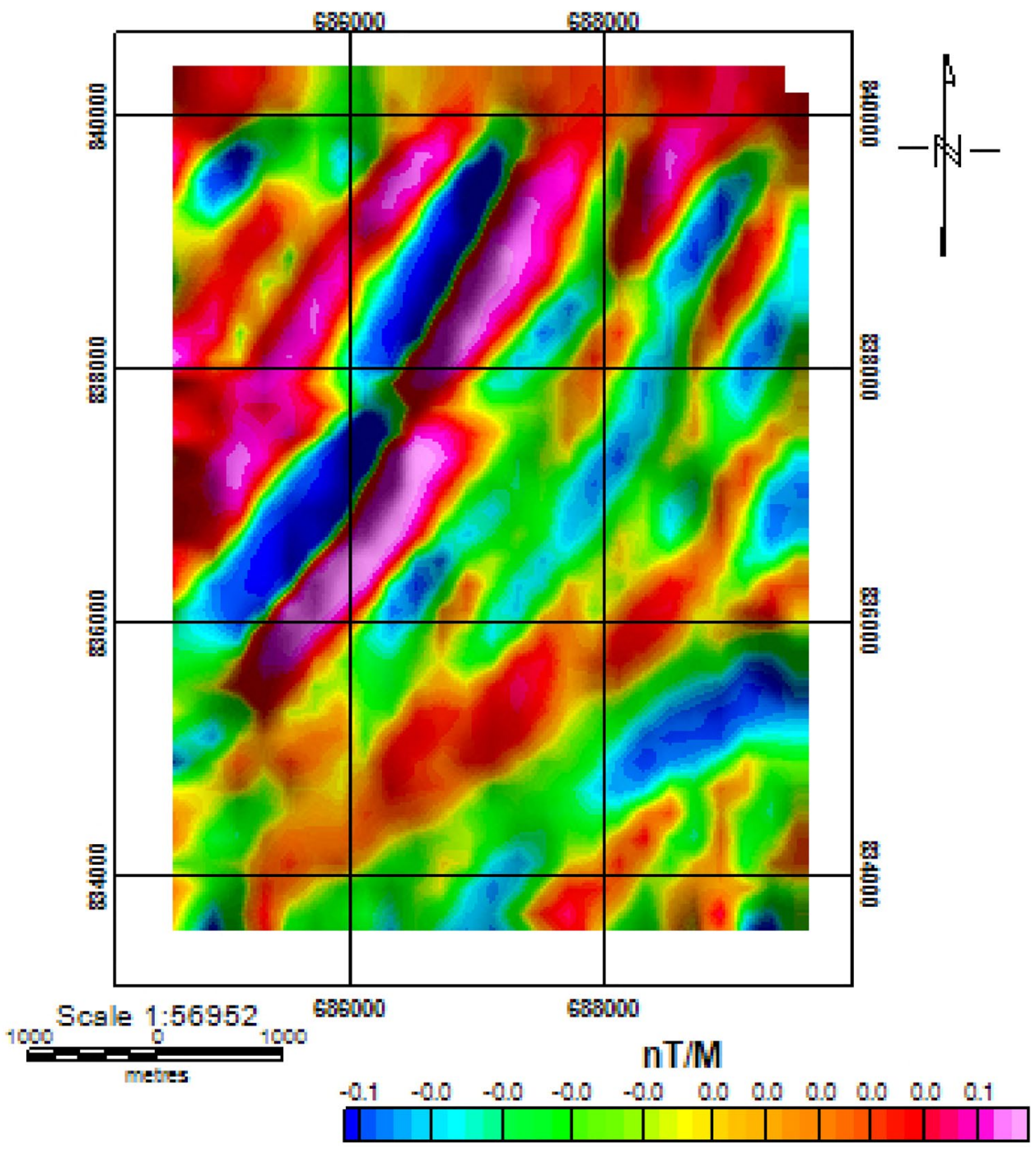

curve showed the change of resistivity with depth, since the effective penetration increases with increasing electrode spacing. The interpretation of the VES curve is both qualitative and quantitative. The qualitative interpretation involved visual inspection of the sounding curves while the quantitative interpretation utilized partial curve matching technique using 2-layer master curve which was later refined by a computer iteration technique Resist version that is based upon an algorithm. The quantitatively interpreted sounding curves gave interpreted results as geo-electric parameters (that is, layer resistivity and layer thickness).

\section{Results and discussion}

\section{Aeromagnetic data}

\section{Total magnetic intensity map (TMI)}

Figure 5 illustrates the TMI image indicating high magnetic susceptible areas in low magnetic values (blue) while low magnetic susceptible areas are depicted as high magnetic values (pink colour). Total magnetic intensity level in the study area ranges from -81.6 to $42.4 \mathrm{nT}$, suggesting contrasting magnetic susceptibilities or variation in groundwater contents of the rock types in the study area. High anomalies were observed which may be attributed to the presence of migmatite gneiss undifferentiated. Negative anomalies were observed in the area which may be due to the presence of 
Fig. 10 Y-Derivative Map of the Study Area

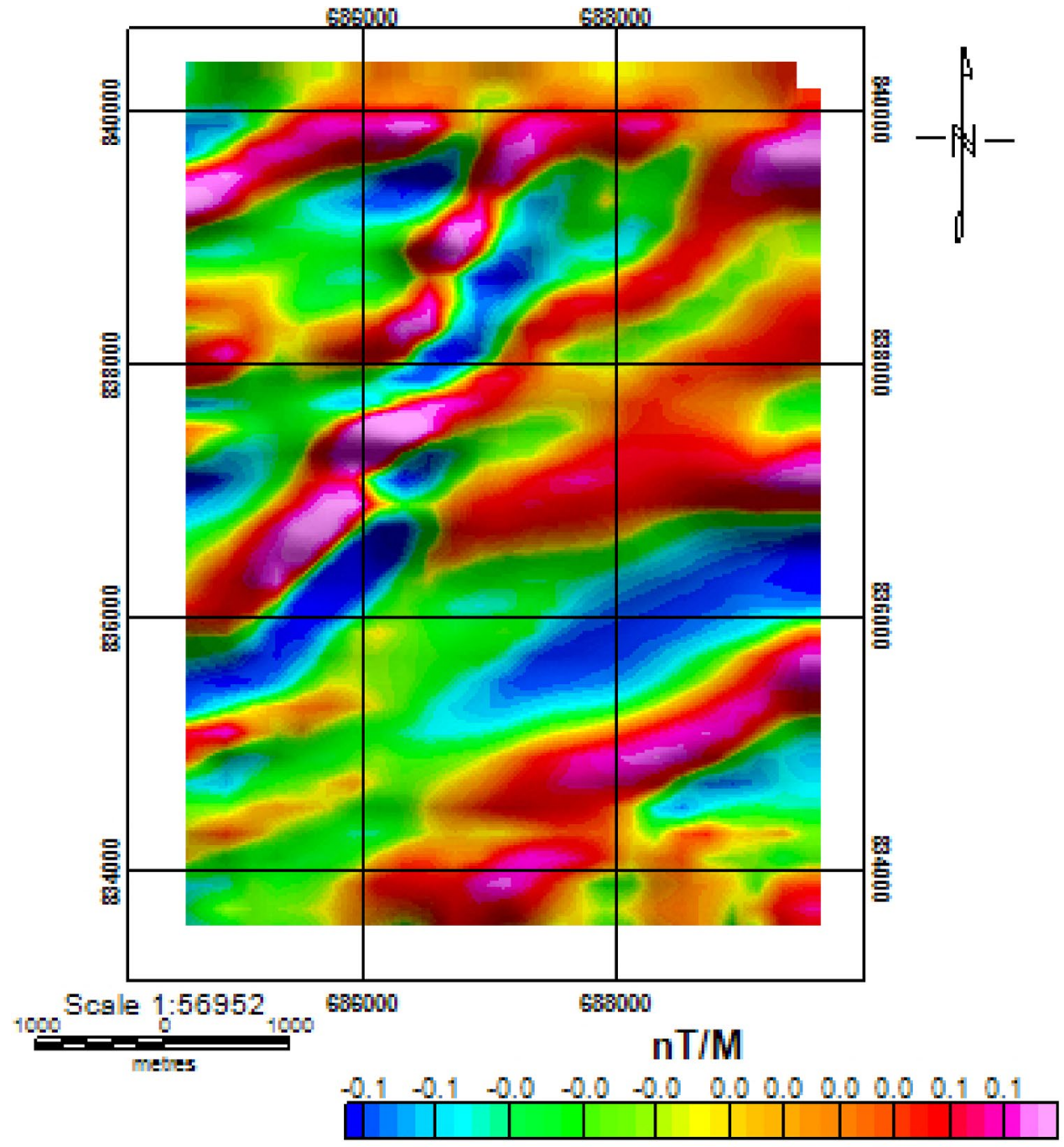

low magnetic rocks (e.g. amphibolite schist) in the area, which are noted for low magnetic signatures (Gilbert and Geldano 1985). The total magnetic field intensity data were gridded using the minimum curvature method. The total magnetic image showed the difference in locations of high and low magnetic intensities. The total field intensity map had earlier been corrected for large varying main earth's magnetic and temporal diurnal fields over the area.

\section{Reduction to the equator (RTE)}

The RTE was performed to preserve low angle of inclination at the equator, thus transforming the source of magnetization to be horizontal (Fig. 6). The output of the RTE is similar to the magnetic anomaly map of the study area because of the low angle of inclination of the area. The RTE map helps to remove magnetic inclination effect in the low magnetic latitude region by centring the peaks magnetic anomalies over their sources and enhancing the basement architecture including structural lineaments with its orientations. Two major magnetic zones were identified based on the magnetic intensity variation over the study area. The northwestern and northeastern parts are dominated by high amplitude magnetic anomalies values (between 4.8 and 39.7 nT). However, towards the southeastern part of RTE, the area is characterized by relative low amplitude magnetic intensity values (between -81.9 and $-5.4 \mathrm{nT}$ ) marked with greenish to blue colour suggests areas characterized by geological structures (fracture/fault) with low magnetic contents likely with capability to serve as groundwater accumulation.

\section{Upward continuation map}

The upward continuation of the processed TMI reduced to equator over the study area continued upwards to $1 \mathrm{~km}$ (Fig. 7). The anomaly patterns identified in this map are a 
Fig. 11 Total Horizontal Derivative Map of the Study Area

Fig.12 Spectral Analysis of the Study Area
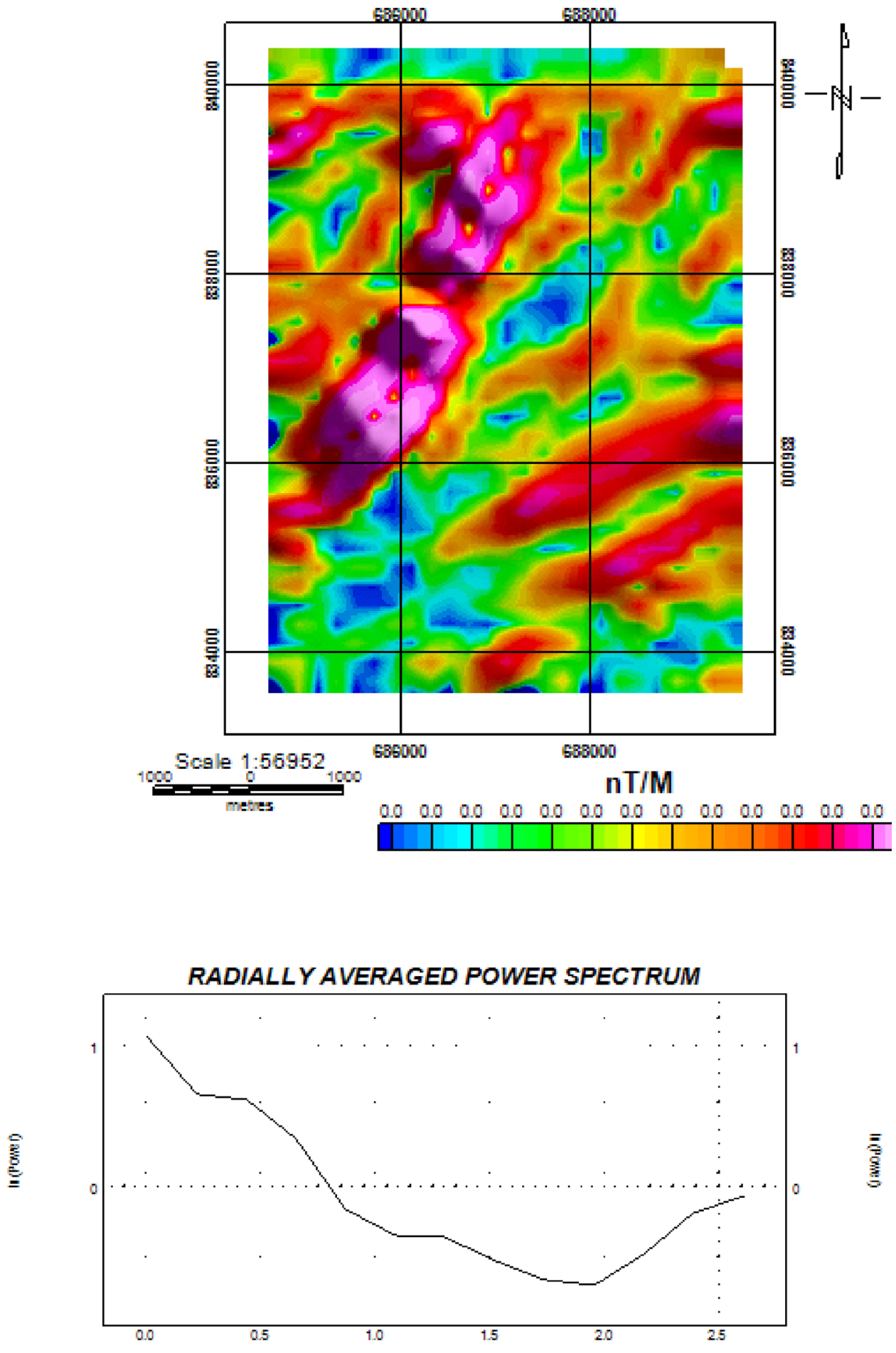

홍

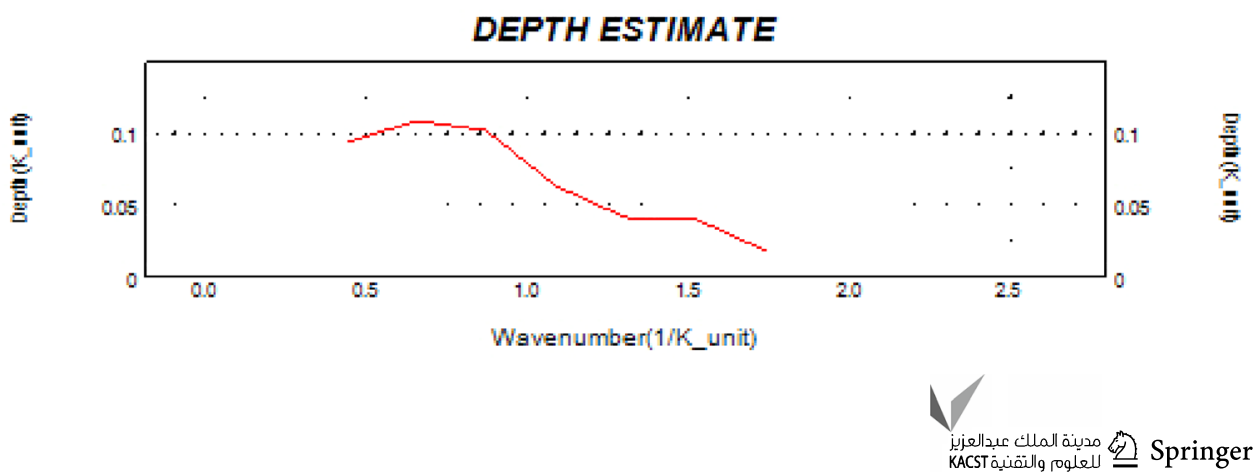




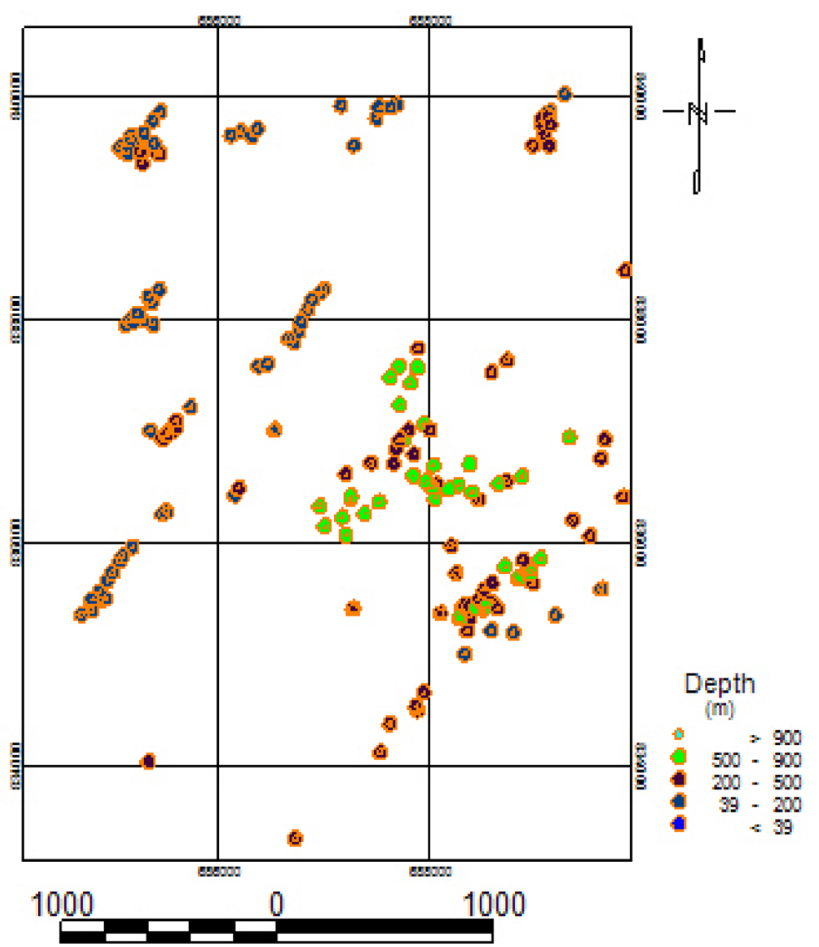

(meters)

Fig. 13 Euler deconvolution S.I=0.5 of the Study Area

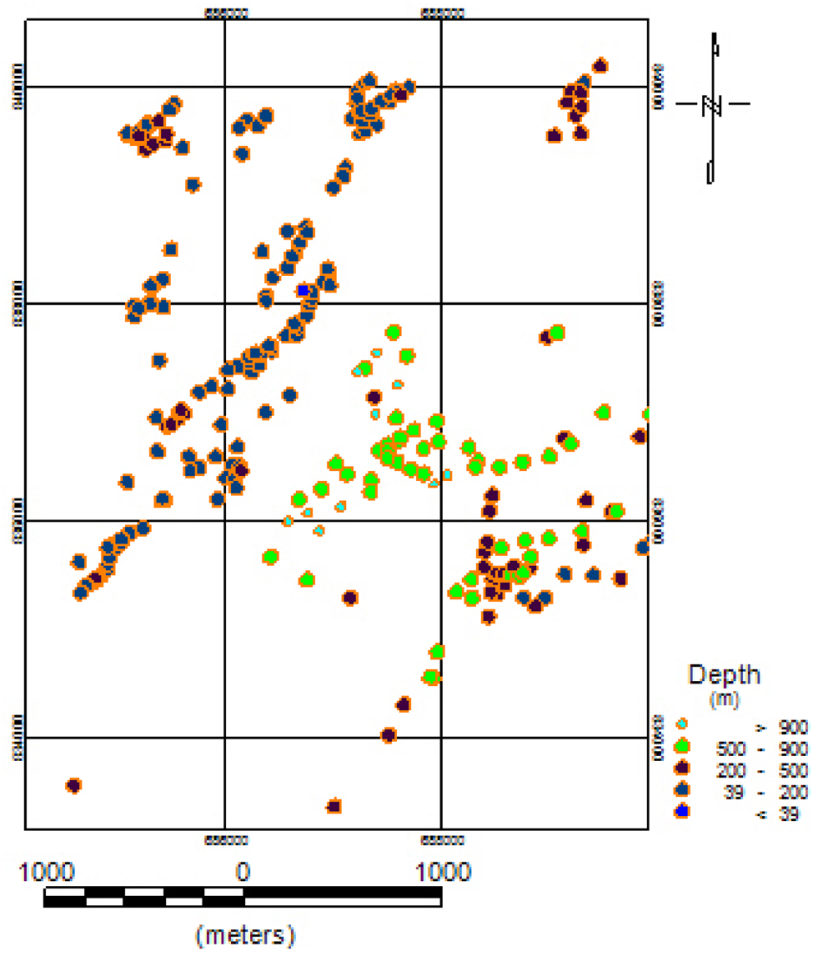

Fig. 14 Euler deconvolution S.I=1.0 of the Study Area qualitative representation of spatial variation in the magnetic properties of deep basement rocks and structures in the area. In physical terms, as the continuation distance is increased, the effects of smaller, narrower and thinner magnetic bodies progressively disappear relative to the effects of larger magnetic bodies of considerable depth extent. As a result, upward continuation maps give the indications of the main tectonic and crustal blocks in an area.

\section{Residual magnetic anomaly map}

The Residual map obtained by removing the computed regional data (long wavelength anomalies) allows for the display of embedded residual anomalies in the original aeromagnetic map (Fig. 8). The residual magnetic anomaly map of the study area illustrated that the dominant magnetic anomaly trends in the study are predominantly in the NE-SW direction with values ranging from -55.7 to $36.1 \mathrm{nT}$. Magnetic lows were within high magnetic reliefs zones at various regions within the study area. In view of the low magnetic latitude of the study area, these magnetic lows are symptomatic of rocks with relatively higher magnetic susceptibility, a good case in point being the anomaly over the amphibolites schist in the southwestern corner of the map.

\section{Horizontal derivative map along $X$-direction}

Derivative filters are applied to enhance aeromagnetic signature of linear magnetic features and provides a means of enhancing anomalies of smaller and near-surface that are associated with geological structures (Fig. 9). The essence is to attenuate the long wavelength anomaly emanated from deep seated bodies and accentuate short wavelength anomaly emanated from shallow seated geological bodies. It allows the extraction of information about the linear structures, contacts and the tectonic setting of the study area. The colour scale horizontal gradient images of the total magnetic intensity enhanced the image by showing major structural and lithological detail which was not obvious in TMI image. Geological structures were well delineated at (NE-SW) which might be considered a fault or fracture.

\section{Horizontal derivative map along $Y$-direction}

Derivative filters are applied to enhance aeromagnetic signature of linear magnetic features and provides a means of enhancing anomalies of smaller and near-surface that are associated with geological structures (Gupta and Ramani 1982) (Fig. 10). The map of the horizontal gradient in $Y$-direction of the study region allows the extraction of information about the linear structures, contacts and the tectonic 
Fig. 15 Lineaments Density Map of the Study Area

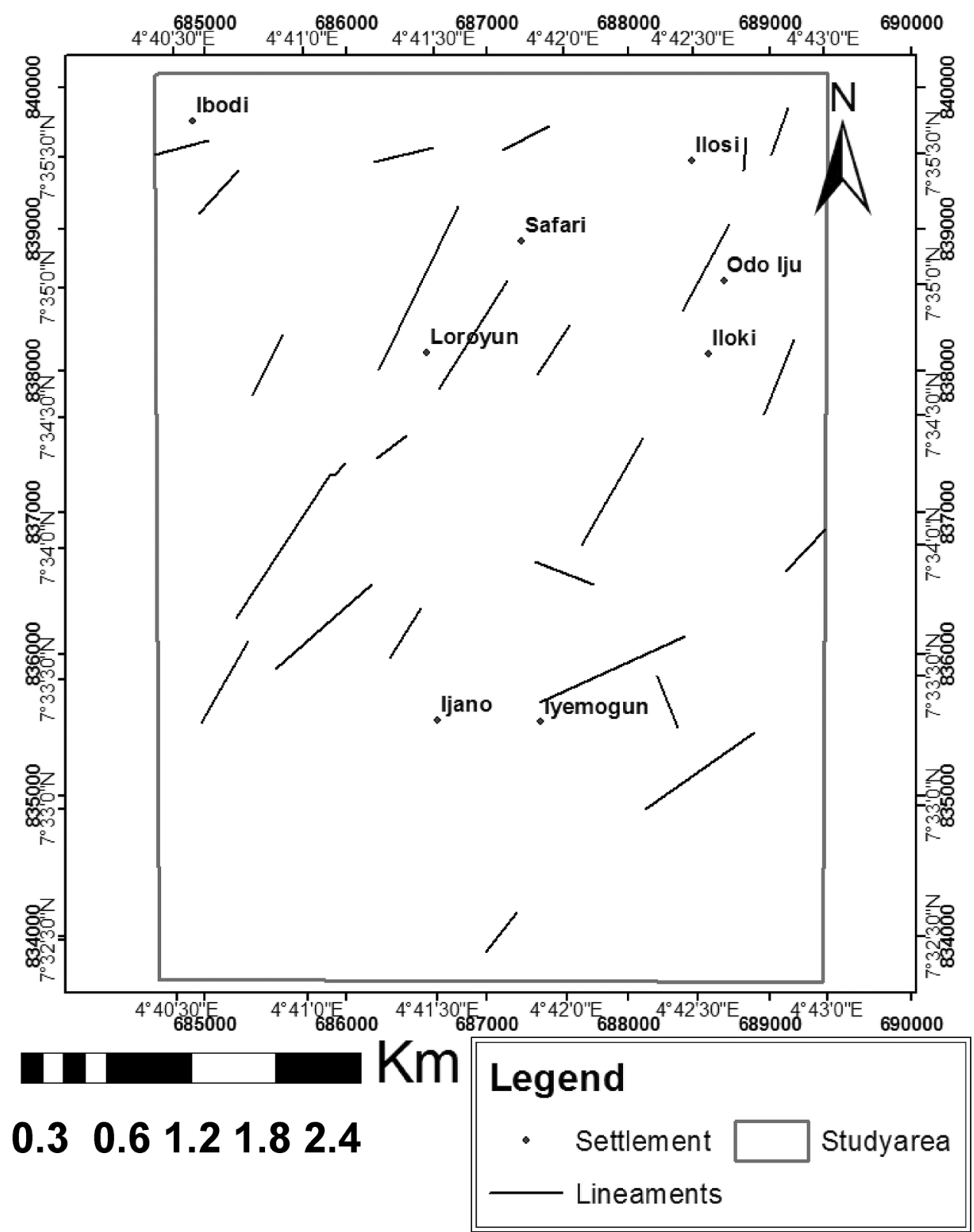

setting. The map patterns dominated by essentially NE-SW striking anomalies are more pronounced.

\section{Total horizontal derivative (THD)}

Total horizontal derivative filter is an effective tool in detecting edges of magnetized structures and it tends to accentuate shallow anomalies (Fig. 11). Total horizontal derivative map was generated from the aeromagnetic data in order to enhance the anomaly curvature of the near-vertical structures arising from the changes of contrasting magnetic susceptibility. It encompasses information of the magnetic field variation along the orthogonal axes completely defining it. Consequently, structural features and boundaries of causative sources can be enhanced. Prominent structurally trend in the NW and SW directions were also in the map observed.

\section{Radially average power spectrum}

The spectral analysis of potential field data which serves as an approximate guide in estimating the depth of magnetic sources was also carried out on reduction to equator (Fig. 12). It shows a typical radial averaged spectrum of the digitized aeromagnetic data and the depth estimate plot. The theoretically average power spectrum of the study area shows a normal plot that has straight line segments which decreases in slope with increasing frequency. From the 


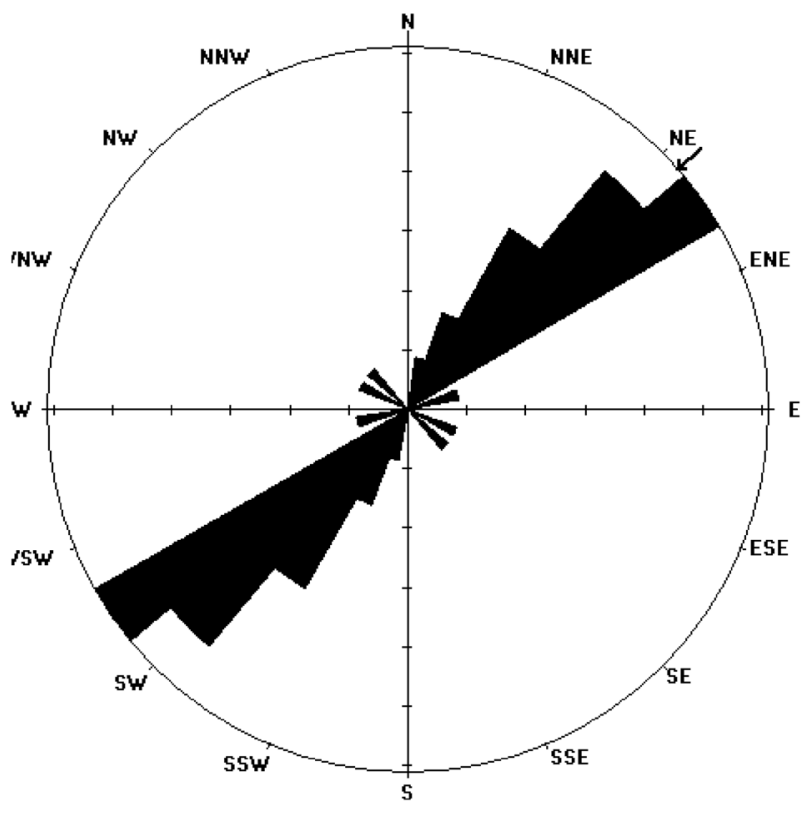

Fig. 16 Rose Diagram of the Study Area

radially average power spectrum depth estimated curve, the depth to the magnetic sources in the area ranged from shallow $80 \mathrm{~m}$ to intermediate $2 \mathrm{~m}$ to deeper $110 \mathrm{~m}$.

\section{Depth estimate using 3D Euler deconvolution}

The Euler deconvolution of the aeromagnetic data was carried out to determine the locations and depth of the source of magnetic anomaly and other geological sources in the area. The methodology adopted was obtaining solutions by inverting Euler homogeneity equation which relates the magnetic field and its gradient components to the location of the source of an anomaly and with the degree of homogeneity expressed as structural index. The Euler deconvolution process was carried out on the aeromagnetic data of the study area using structural index of 0.5 and 1 (Barbosa et al. 1999) (Figs. 13 and 14). During the processing on Oasis Montaj software, the structural index of 0.5 and 1 yielded a window size of 5 corresponding to $100 \mathrm{~m}$ a maximum distance of the source and a minimum depth tolerance of $15 \%$. Depth range from 39 to $987 \mathrm{~m}$ and 39-1232 $\mathrm{m}$ was obtained, which show relatively shallow depth as related to delineated rock of boundaries. The extracted lineaments reflect the position of features such as fault, deep fractures and geological contacts.

\section{Aeromagnetic lineaments map}

3D Euler solution for the aeromagnetic data of the study area, at Structural Index ( $\mathrm{S} . \mathrm{I}=0.5$ and 1$)$ that was produced using the GEOSOFT packages was importing into ArcGIS environment. It was geo-referencing and digitized to generate aeromagnetic lineament map in ArcGIS 10.5 environment with other derivatives to demonstrate the usefulness of aeromagnetic structures in lineament mapping and analysis, i.e. to delineate geological structures (fault, fracture, joint, etc.) in the study area (Hsu 2002; Kivior and Boyd 1998). In total, 25 lineaments were extracted from the aeromagnetic structure (Fig. 15). The arose diagram prepared from the extracted lineaments on the aeromagnetic structures shows that there is one predominant set of lineament which are closely related to tectonic activities such as fractures, faults and joints in the study area (Fig. 16). One set of the lineaments trends NE-SW directions. Major lineaments are dominated at the southeastern part whereas there are traces of minor lineament at the northeastern and central part of the study area.

\section{Hydrogeological significance of lineament density map}

Lineament density map is one of the important maps prepared from the lineaments, which area critically used in groundwater studies related to hard rock terrain. Figure 17 shows the aeromagnetic lineament density map of the study area. Areas with high lineament density excluding (the residual hill environment) are good for groundwater development. The map shows four different hydrogeological potential zones distributed as patches in the study area. The zones are summarized in Table 1, respectively. Regarding groundwater exploration, these aforementioned areas may have high groundwater potentials due to their high concentration of lineaments, i.e. since groundwater occurs within faults and fractures in the basement rocks.

\section{Vertical electrical sounding}

Data acquired from vertical electrical sounding (VES) using Schlumberger configuration were interpreted, first using manual partial curve matching techniques, and later subjected to computer iterative modelling. Figure 18a-c shows typical iterated VES data curves and the estimated geo-electric parameters. In the study area, three (3) curve types were identified, these are $\mathrm{H}, \mathrm{HA}$ and $\mathrm{KH}$. 
Fig. 17 Hydrogeological Significance of Aeromagnetic Lineament Density Map of the Study Area

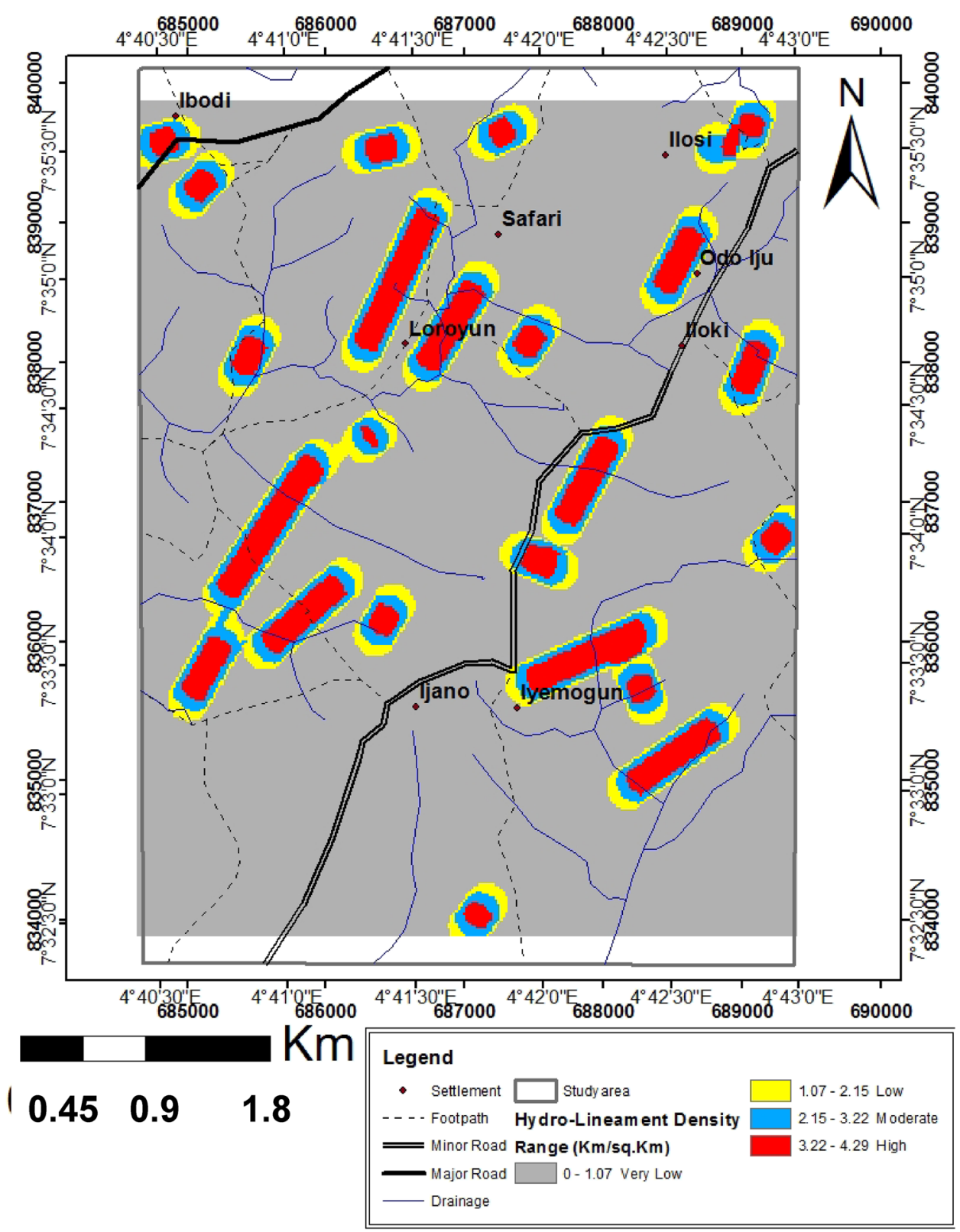

\section{Superposition of vertical electrical sounding (VES)} on aeromagnetic lineament density

Figure 19 indicates the superposition of vertical electrical sounding (VES) on aeromagnetic Lineament Density. The result from the VES data reflects that the areas where the hydro-lineament density has tendency of very high groundwater prospect. This illustrates that the area will be good for groundwater development. Considering the groundwater potential classification, it is clear from the magnetic lineament density

\begin{tabular}{lcl}
\hline $\begin{array}{l}\text { Lineaments density } \\
\text { colour code }\end{array}$ & $\begin{array}{l}\text { Lineaments density range } \\
(\mathrm{km} / \mathrm{sq} . \mathrm{km})\end{array}$ & $\begin{array}{l}\text { Ground- } \\
\text { water } \\
\text { prospect }\end{array}$ \\
\hline Lemon & $0-1.07$ & Very low \\
Yellow & $1.06-2.15$ & Low \\
Blue & $2.15-3.22$ & Moderate \\
Red & $3.22-4.29$ & High \\
\hline
\end{tabular}



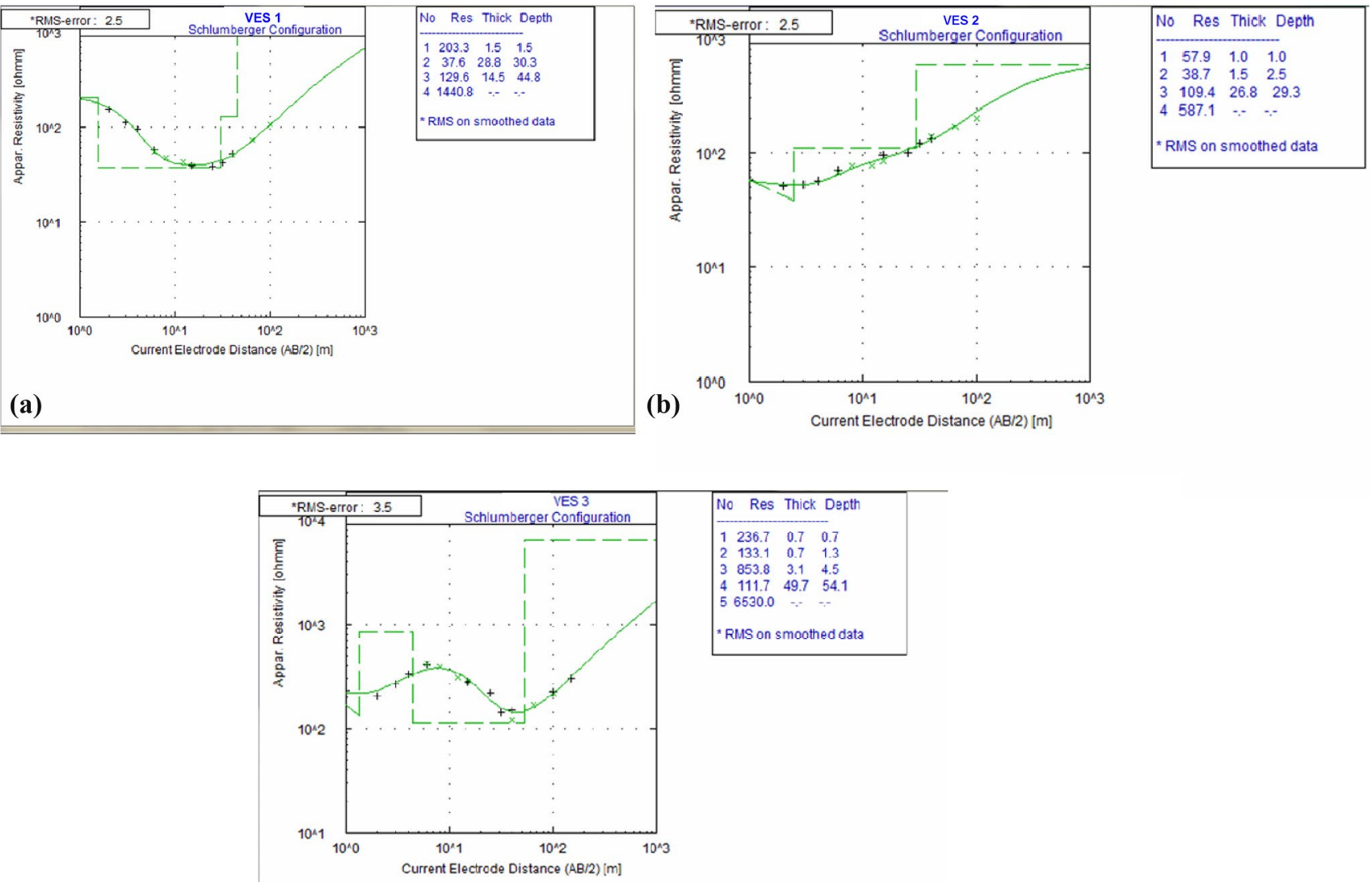

(c)

Fig. 18 a. Typical Curve Types: H Curve. B Typical Curve Types: HA Curve. c Typical Curve Types: KH Curve

hydro-lineament density map that area with red colours displays tendencies for very high groundwater potential. The blue colour reflects medium groundwater potential tendencies, while yellow and lemon colour characterize low and very low groundwater potential. The VES data correlate well with the hydro-lineament density map for groundwater potential evaluation.

\section{Conclusion}

In this research, groundwater potential investigated has been carried using electrical resistivity and aeromagnetic methods. In order to map out the geological structures of the study area, magnetic image enhancing filters applied to the total magnetic intensity (TMI) using Geosoft (Oasis Montaj) are reduction to equator (RTE), vertical derivative (VD), total horizontal derivative (THD) and upward continuation (UC). These filters helped define the lithological boundaries, geological structures, faults, folds and contacts. The lineament of aeromagnetic map was generated from derived field intensity gradients and solutions of
Euler deconvolution carried out on the aeromagnetic data using structural index of 0.5 and 1 . The processed image shows the lineaments trends majorly towards NE-SW directions. The 3D Euler deconvolution and radial spectral analysis applied to locate and estimate the depth to anomalous bodies show varying depth between 39 and $1200 \mathrm{~m}$. From these combined results of the study area, consistent aeromagnetic lineament map was generated showing the probable positions and trends of the suspected fractured/a faulted zone as well as other basement structures. The map revealed the presence of major and minor faults, fractures as well as rock boundaries with the frequency of fracturing. This suggests that the major fractures and faults in the study area are deep within the basement formation since the spectral analysis enhances the anomalies associated with deep magnetic sources at the expense of the dominating intermediates magnetic sources. The processed image displays the lineaments trending NE-SW directions. Hydro-lineament density maps based on lineament were produced from the generalized structure trends in the area. The result from the depth sounding data interpretation indicates three curve types which are $H, \mathrm{HA}$ and $\mathrm{KH}$, 
Fig. 19 Superposition of Vertical Electrical Sounding (VES) on Aeromagnetic Lineament Density

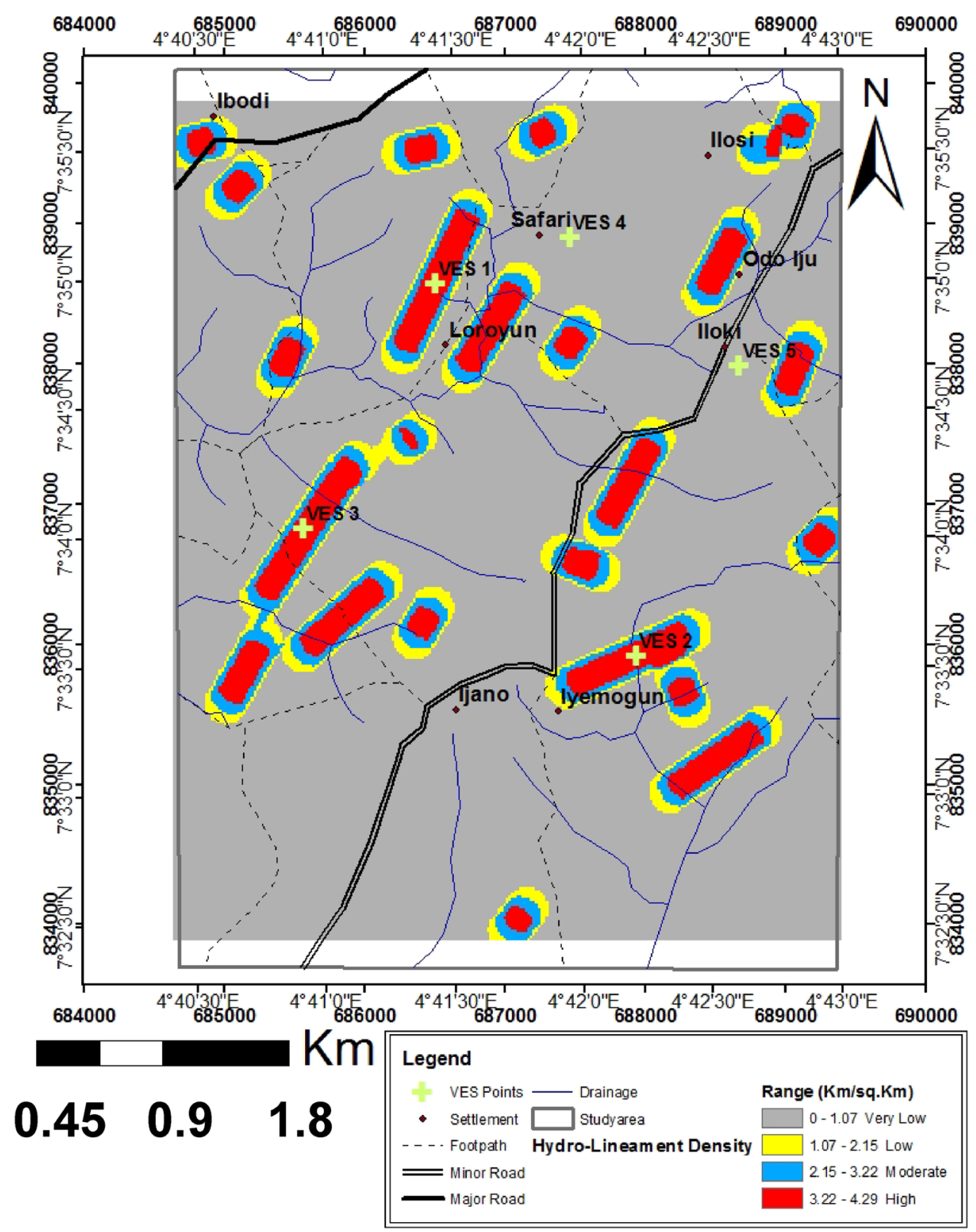

From the lineaments map generated from study area, the map can be analytically viewed from the point of foundation studies and solid minerals. The southeastern and northeastern part have major structural trends that maybe favourably dispose to solid mineral deposit.

In terms of foundation studies, this part of the study area may be of major concern to structural engineers and builders, whereas the northern, northeastern and part of the central east may not be favourably dispose to solid mineral deposit, as well as low groundwater potential, but however, may have less problem in terms of foundation studies. Therefore, this type of study is very relevant for both now and future planning of landuse and development. to successfully evaluate Ibodi and its environs in terms of groundwater development and production. where curve type $H$ has the highest occurrence. The results area will be good for groundwater development. The study has led to the delineation of areas where groundwater occurrences are most promising for sustainable supply, sesting that an area with high concentrations of lineament density has a high tendency for groundwater prospecting. The results from the study show that the aeromagnetic technique is capable of extracting lineament trends 
Funding The authors declare that we do not receive funding throughout this research.

Open Access This article is licensed under a Creative Commons Attribution 4.0 International License, which permits use, sharing, adaptation, distribution and reproduction in any medium or format, as long as you give appropriate credit to the original author(s) and the source, provide a link to the Creative Commons licence, and indicate if changes were made. The images or other third party material in this article are included in the article's Creative Commons licence, unless indicated otherwise in a credit line to the material. If material is not included in the article's Creative Commons licence and your intended use is not permitted by statutory regulation or exceeds the permitted use, you will need to obtain permission directly from the copyright holder. To view a copy of this licence, visit http://creativecommons.org/licenses/by/4.0/.

\section{References}

Ademeso OA, Adekoya JA, Adetunji A (2013) Further evidence of cataclasis in the ife-ilesa schist belt, southwestern Nigeria. J Nat Sci Res 3(11):50-59

Ajayi TR, Ogedengbe O (2003) Opportunity for the Exploitation of Precious and Rare Metals in Nigeria. In: Elueze AA (ed) Prospects for Investment in Mineral Resources of Southwestern Nigeria, pp $15-26$

Ajibade, A.C. (1979). The Nigerian precambrian and the Pan-African orogeny. In: Oluyide, P.O. (Ed.), Precambrian Geology of Nigeria. Proceedings, Geological Survey of Nigeria, 45-53

Akinlalu AA, Adelusi AO, Olayanju GM, Adiat KAN, Omosuyi GO, Anifowose AYB, Akeredolu BE (2018) Aeromagnetic mapping of basement structures and mineralisation characterisation of Ilesa Schist Belt, Southwestern Nigeria. J Afr Earth Sci 138:383-391

Anifowose AYB, Borode AM (2007) A photogeological study of the fold structure in Okemesi area. Niger J Min Geol 43(2):125-130

Barbosa VCF, Silva JBC, Medeiros WE (1999) Stability analysis and improvement of structural index estimation in Euler deconvolution. Geophysics 64:48-60

Batista-Rodriguez JA, Caballero A, Perez-Flores M, Carmenates A, Almaguer Y (2017) 3DInversion of aeromagnetic data on Las Tablas District, Panama. J Appl Geophys. https://doi.org/10. 1016/j.jappgeo.2017.01.018

Djamel B (2017) Combining resistivity and aeromagnetic geophysical surveys for groundwater exploration in the Maghnia Plain of Algeria. J Geol Res. https://doi.org/10.1155/2017/1309053

Dobrin MB, Savit CH (1988) Introduction to geophysical prospecting. McGraw-Hill Book Co. Inc., New York

Elueze AA (1982) Petrology and gold mineralization of the amphibolites belt. Ilesha Area Southwest Niger Geol Enmijnbouw 65:189-195

Emujakporue G, Ofoha C, Kiani I (2017) Investigation into the basement morphology and tectonic lineament using aeromagnetic anomalies of Parts of Sokoto Basin, North Western, Nigeria. Egypt J Petrol. https://doi.org/10.1016/j.ejpe.2017.10.003

Essa K, El-Hussein M (2017) 2D dipping dike magnetic data interpretation using a robust particle swarm optimization. Geosci Instrum Methods Data Syst Discuss. https://doi.org/10.5194/ gi-2017-39.1-20

Gilbert D, Geldano A (1985) A computer programme to perform transformations of gravimetric and aeromagnetic surveys: computers and geosciences 11:553-588
Griffiths DH, Turnbull J, Olayinka AI (1990) Two-dimensional resistivity mapping with a computer-controlled array. First Break 8(4):121-129

Griffiths DH, Turnbull J (1985) A multi-electrode array for resistivity surveying. First Break 3(7):16-20

Gunn PJ (1997) Quantitative methods for interpreting aeromagnetic data: a subjective review. AGSO J Aust Geol Geophys 17(2):105-113

Gupta VK, Ramani N (1982) Optimum second vertical derivatives in geological mapping and mineral exploration. Geophysics 47:1706-1715

Hsu SK (2002) Imaging magnetic sources using Euler's equation. Geophys Prospect 50:15-25

Geosoft Inc (2012) Oasis montaj www.geosoft.com/products/oasismontaj New Geosoft 2012 Release

Joel, E. S., Olasehinde, P. I., De1, D. K., Maxwell, O. (2016) Regional Groundwater Studies Using Aeromagnetic Technique. Adapted from extended abstract based on oral presentation given at AAPG/ SEG International Conference \& Exhibition, Cancun, Mexico, September 6-9, 2016

Kayode JS, Adelusi AO, Nyabeze PK (2011) Horizontal derivatives of the ground magnetic interpretation in part of Ilesha Area. Southwest Niger Sci Res Essays 6(20):4163-4171

Kearey P, Brooks M, Hill J (2002) An introduction to geophysical exploration, 3rd edn. Blackwell Science, Oxford, pp 155-221

Kivior I, Boyd D (1998) Interpretation of the aeromagnetic experimental survey in Eromanga/Cooper Basin. Can J Explor Geophys 34:58-66

Musa OK, Ogbodo DA, Jatto SS, Kudamnya EA (2013) Evaluation of groundwater potential of crystalline basement area of Kogi State Polytechnic, Osara Campus, North-Central Nigeria using electrical resistivity method. J Environ Earth Sci 3(9):171-183

Nabighian MN (1984) Towards a three-dimensional interpretation of potential field data via generalised Hilbert transforms: fundamental relations. Geophysics 49:780-786. https://doi.org/10. 1190/1.1441706

Nabighian MN (1974) Addition comments on the analytic signal of two dimensional magnetic bodies with polygon cross-section. Geophysics 39:85-92

Ndikilar CE, Idi BY, Terhemba BS, Idowu II, Abdullahi SS (2019) Applications of aeromagnetic and electrical resistivity data for mapping spatial distribution of groundwater potentials of Dutse, Jigawa State, Nigeria. Mod Appl Sci 13:11-20

Osazuwa IB (1988) Cascade model for the removal of drift from gravimeter data. Surv Rev 29(228):295-303

Osinowo O, Akanji A, Olayinka A (2013) Application of high resolution aeromagnetic data for basement topography mapping of Siluko and environs, southwestern Nigeria. J Afr Earth Sc. https:// doi.org/10.1016/j.jafrearsci.2013.11.005

Oyinloye AO (2011) Geology and Geotectonic Setting of the Basement Complex Rocks in South Western Nigeria: implications on Provenance and Evolution. Earth and Environmental Sciences, Imran Ahmad Dar and Mithas Ahmad Dar, IntechOpen. pp 5-118. https://doi.org/10.5772/26990

Parker Gay S (1963) Standard curves for interpreting magnetic anomalies over long tabular bodies. Geophysics 28:161-200. https://doi. org/10.1190/1.1439164

Qin S (1994) An analytic signal approach to the interpretation of total field magnetic anomalies. Geophys Prospect 42:665-675. https:// doi.org/10.1111/j.1365-2478.1994.tb00234.x

Rahaman MA (1988) Recent advances in the study of the Basement Complex of Nigeria. In: Oluyide PO, Mbonu WC, Ogezi AE, Egbuniwe IG, Ajibade AC, Umeji AC (eds) Precambrian Geology of Nigeria, Kaduna, Nigeria. pp 11-43 
Rambabu HV, Sinha GDJ (1986) Magnetic anomalies over thin plates and their analysis. Earth Planet Sci 95(3):331-341

Reid AB, Allsop IM, Granser R, Millet AL, Somerton IW (1990) Magnetic interpretations in three dimensions using Euler deconvolution. Geophysics 55:80-91. https://doi.org/10.1190/1.1442774

Roest WR, Verhoef V, Pilkington M (1992) Magnetic interpretation using the 3-D analytic signal. Geophysics 57:116-125. https:// doi.org/10.1190/1.1443174

Sharma PV (1997) Environmental and engineering geophysics. Cambridge University Press, Cambridge, $\mathrm{p} 475$

Spector A (1971) Aeromagnetic map interpretation with the aid of digital computer. CIM Bull 64:67-33

Spector A, Grant FS (1970) Statistical models for interpreting aeromagnetic data. Geophysics 35:293-302. https://doi.org/10.1190/1. 1440092
Srivastava A (2002) Aquifer geometry, basement-topography and ground water quality around Ken Graben, India. J Spat Hydrol 2(2): $1-18$

Steinich B, Bocanegra G, Sánchez E (1999) Basement topography and fresh-water resources of the coastal aquifer at Acapetahua, Chiapas, Mexico. Geofís Int 38(2):107-115

Thompson R (1973) Paleomagnetism and Paleolimnology. Nature 242:182-184

Thompson DT (1982) EULDPH: a new technique for making computer-assisted depth estimates from magnetic data. Geophysics 47:31-37

Won IJ, BeviS MG (1987) Computing the gravitational and magnetic anomalies due to a polygon: algorithms and Fortran subroutines. Geophysics 52:232-238. https://doi.org/10.1190/1.1442298 